\title{
Introducing and engaging diverse high school students to biophotonics through multi-year courses
}

\section{Marco Molinaro, Pamela Castori, Mike Wright, Ana Corbacho}

Marco Molinaro, Pamela Castori, Mike Wright, Ana Corbacho, "Introducing and engaging diverse high school students to biophotonics through multi-year courses," Proc. SPIE 9665, Tenth International Topical Meeting on Education and Training in Optics and Photonics, 96651A (3 June 2007); doi: 10.1117/12.2207532

SPIE Event: Tenth International Topical Meeting on Education and Training in Optics and Photonics, 2007, Ottawa, Ontario, Canada 


\title{
Introducing and Engaging Diverse High School Students to Biophotonics Through Multi-Year Courses
}

\author{
Marco Molinaro. Pamela Castori, Mike Wright, and Ana Corbacho \\ Center for Biophotonics Science and Technology, University of California, Davis, One Shields Avenue, Davis, CA, USA 95616; \\ 530-754-5305; mmolinaro@ucdavis.edu; http://cbst.ucdavis.edu
}

\begin{abstract}
The National Science Foundation (NSF) funded Center for Biophotonics Science and Technology (CBST) has created various high school biophotonics research academies for both students and teachers from diverse socioeconomic backgrounds. These academies engage diverse students for 10 hours to over 350 hours per year for multiple years with an emphasis on learning the basics of biophotonics and then conducting original, team-based research. We have developed three versions of the academy, one focused on biology and biophotonics, one on cancer and biophotonics, and a third on plants and biophotonics. A fourth emphasis on biomedical engineering and biophotonics is planned. We have conducted one of these academies for three years and have had very good student retention and science fair winners. As part of our program we also have a summer academy for training teachers. Challenges have arisen amongst the various levels of Academies, chief among them sustainability. In the future, more extensive evaluation, curriculum consolidation, and widespread dissemination are critical.
\end{abstract}

\section{Introduction}

The Education and Human Resources Program of the Center for Biophotonics Science and Technology (CBST) is committed to the goal of increasing the quality and quantity of science education experiences available to a diverse population of students, educators, and the public. We are accomplishing this by developing and implementing an innovative program that establishes pathways to careers in the emerging field of biophotonics. Applications of biophotonics range from using light to image or selectively treat tumors, to sequencing DNA and identifying single biomolecules within cells. ${ }^{1}$ The CBST educational program is a comprehensive educational package that links "the learning years to the earning years."

The inauguration of the Science and Technology Center (STC) program at the National Science Foundation in 1987 represented a fundamental shift in scientific funding policy in the United States, ${ }^{2}$ viz., a move from individual principal investigators to large, multi-investigator, multi-institutional centers. Well established by 2002, the STC program added six new centers, including CBST for which the University of California, Davis was the lead campus. Partner institutions include Lawrence Livermore National Laboratory, UC Berkeley, UC San Francisco, Alabama A\&M University, Stanford University, University of Texas at San Antonio, Fisk University and Mills College. Roughly 100 researchers, including physical scientists, life scientists, physicians and engineers, are collaborating in this rapidly developing area of research.

CBST is now nearing the end of its fifth year of operation. Science and Technology Centers have typically operated for a ten-year period. Although the earliest STC's have now finished their NSF funding cycles, many have been institutionalized as permanent research centers. There are currently 17 STC's funded by NSF. A benefit of the community of STC's is networking and collaboration among different centers. The Center for Adaptive Optics, started in 2000 and headquartered at the University of California, Santa Cruz, has been an especially useful collaboration for CBST. Similarly, the annual meeting of the NSF Research Center Educators Network (NRCEN), a gathering of educational specialists from the various STC's and similar NSF-funded centers such as Engineering Research Centers

Tenth International Topical Meeting on Education and Training in Optics and Photonics, edited by Marc Nantel, Proc. of SPIE Vol. 9665, 96651A · @ 2007 SPIE, OSA, IEEE, ICO doi: $10.1117 / 12.2207532$ 
(ERC) and Materials Research Science and Engineering Centers (MRSEC), is a highly effective forum for sharing best practices for educational programs.

CBST currently provides educational opportunities from a middle school summer camp to advanced graduate courses. Pre-college courses tend to provide a stimulating access to the sciences (evenly balanced between the physical and biological sciences) while undergraduate courses provide a general introduction to the field of biophotonics and graduate courses give advanced training in specific topics within the field. This paper focuses on the CBST efforts with the high school audience, students ages 14-18 and their teachers, that have been carried out since Center inception.

\section{Program Description}

The High School Biophotonics Research Academy (HSRAB) is a high school enrichment program that demonstrates the relevance of Biophotonics in medicine, industry, and research and that challenges students' ideas about careers in science. This program engages students in inquiry-oriented activities and research projects. The curriculum is steered by emerging conceptual models of biophotonics, emphasizes information technology, scientific inquiry and biology/physics/chemistry concepts through studying the applied field of Biophotonics. Program designs from simplest to most involved include (1) integration as a module or unit into an existing course; (2) 200+ hour/year after school programs; (3) in school elective courses and/or college preparatory laboratory courses. Over thirty, 1 to 10 hour long, activities have been created through collaborations between CBST education and research staff and local high school teachers since program inception. These activities come in several variations depending on the particular focus of the HSRAB implementation. In the last three years there have been HSRAB implementations focused on biophotonics, plant biology and biophotonics, and cancer science and biophotonics. In the coming years, a biomedical engineering focused set of activities/curriculum is planned.

\subsection{Program Design 1: Integration as Modules}

By far the simplest manner in which biophotonics has been included in high school curricula has been through interested teachers incorporating one or more activities into an existing biology or physics course. As teachers complete the first two levels of the CBST Summer Biophotonics Research Academy Professional Development series (Level I 3 days, Level II -5 days) they are given copies of our basic biophotonics activities and are automatically eligible to check out specialized equipment. This equipment includes items such as: pulse oxymeters, lasers, light sources, basic USB microscopes, PASCO GLX data loggers, and Ocean Optics Fiber-based spectrophotometers. Most often the teachers report back using 3 to 4 activities which they modify to fit on-site needs. The activities have been incorporated as 1-2 week units in a course, as a "Science Friday" set of activities during a semester, and as the last 2-3 weeks of a school year once the Advanced Placement (AP) exams have been completed (for advanced placement biology usually mid May).

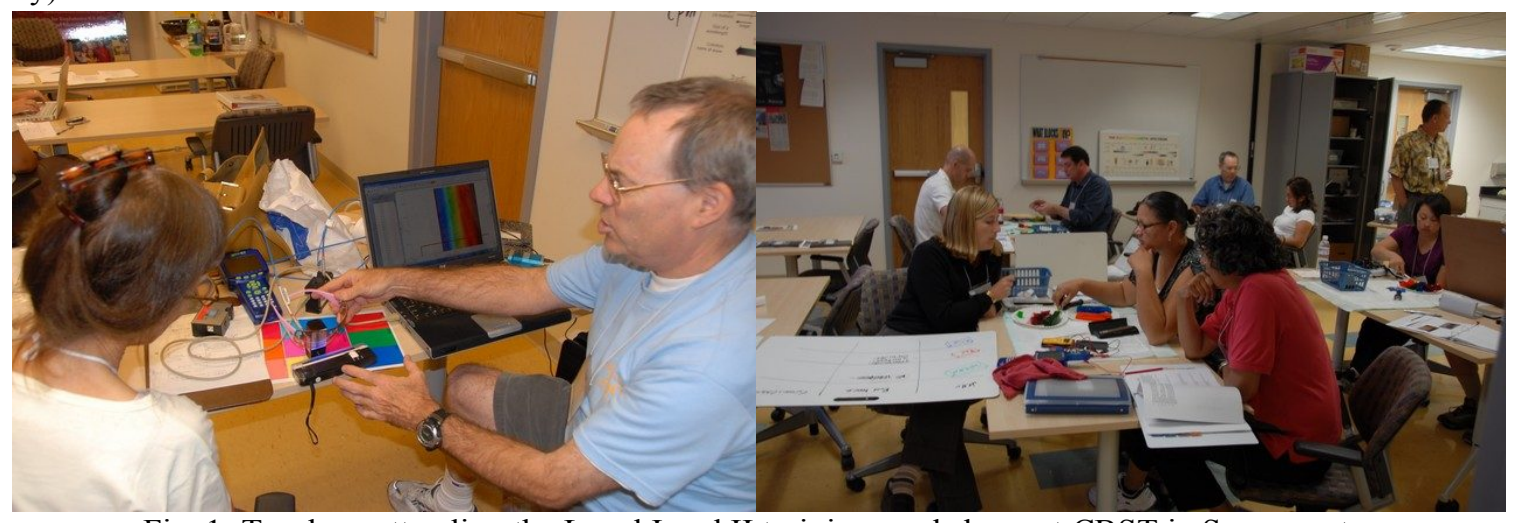

Fig. 1. Teachers attending the Level I and II training workshops at CBST in Sacramento.

\subsection{Program Design 2: After-School Elective}

The after-school elective design was the first design implemented back in 2004 at Center High School in Antelope, California, just north of Sacramento. A competitive application process targets highly motivated and responsible 
students but de-emphasizes their grades as long as it is above a "C". The Center High School population is highly diverse and socioeconomically disadvantaged. Many students attending the school need to supplement their family's income through after-school work. To attract these students to the program, a basic stipend for their participation is offered. The lead teacher, a 20+ year veteran of high school biology teaching, runs the program that regularly meets from 5-7:30 pm, 2 days a week. He is assisted by CBST education staff on a weekly basis and conducts various handson activities and field-trips. Three undergraduate students from UC Davis also participate as student mentors starting in the second semester. The mentors act as role models and help student teams with their individual research projects.

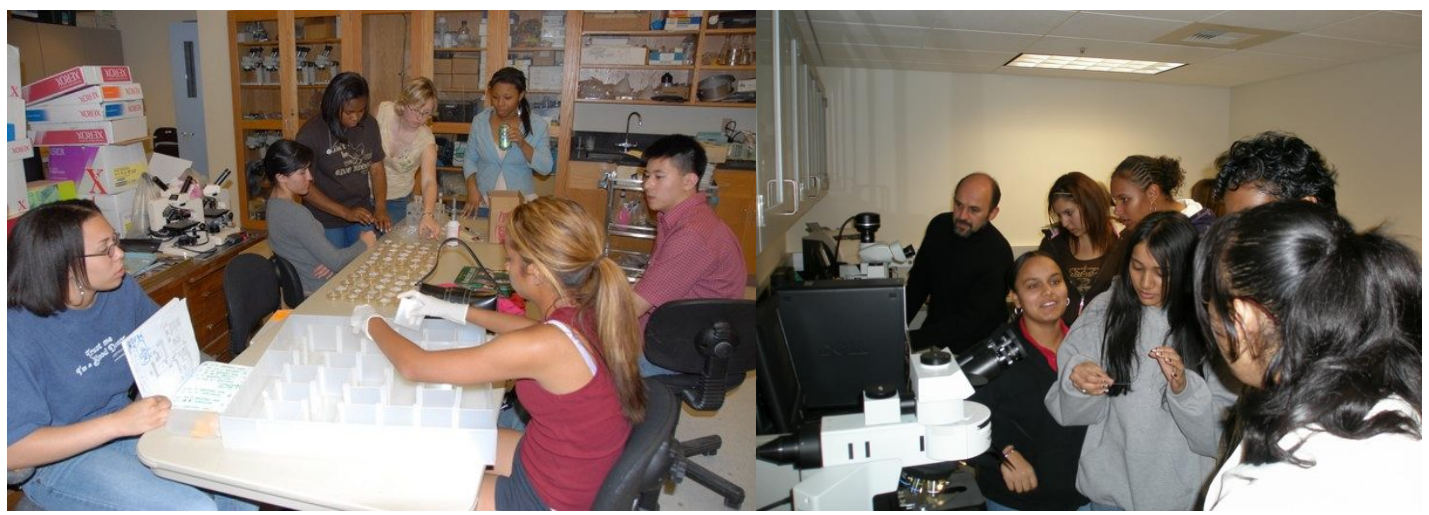

Fig. 2. Center High School students engaged in research and visiting CBST headquarters.

During the first year of this 200+ hour academy, students (1) engage in inquiry-oriented activities; (2) work in small research teams to design a systematic Biophotonics investigation; and (3) are introduced to research and industry opportunities through field-study trips and interaction with CBST research scientists. The year culminates with a research symposium. Students who successfully completed the first year are eligible to continue their study for a second year during which they can continue their research and prepare a competitive biophotonics science fair project. After the second year, they may also apply for internships as they become available.

In the last two years, numerous second year Academy students (Associates) successfully competed in regional science fairs. In 2006, six students competed in the Sacramento Regional Science and Engineering Fair and won first and second place in the team science event, three went on to compete in the California State Science Fair. In 2007, two teams won awards at the Sacramento Science and Engineering Fair; first place in the Molecular and Cellular Biology Category, and an award from the Society for In-Vitro Biologists. These student research teams were supported by four undergraduate mentors, three of which have mentored for over 2 years.

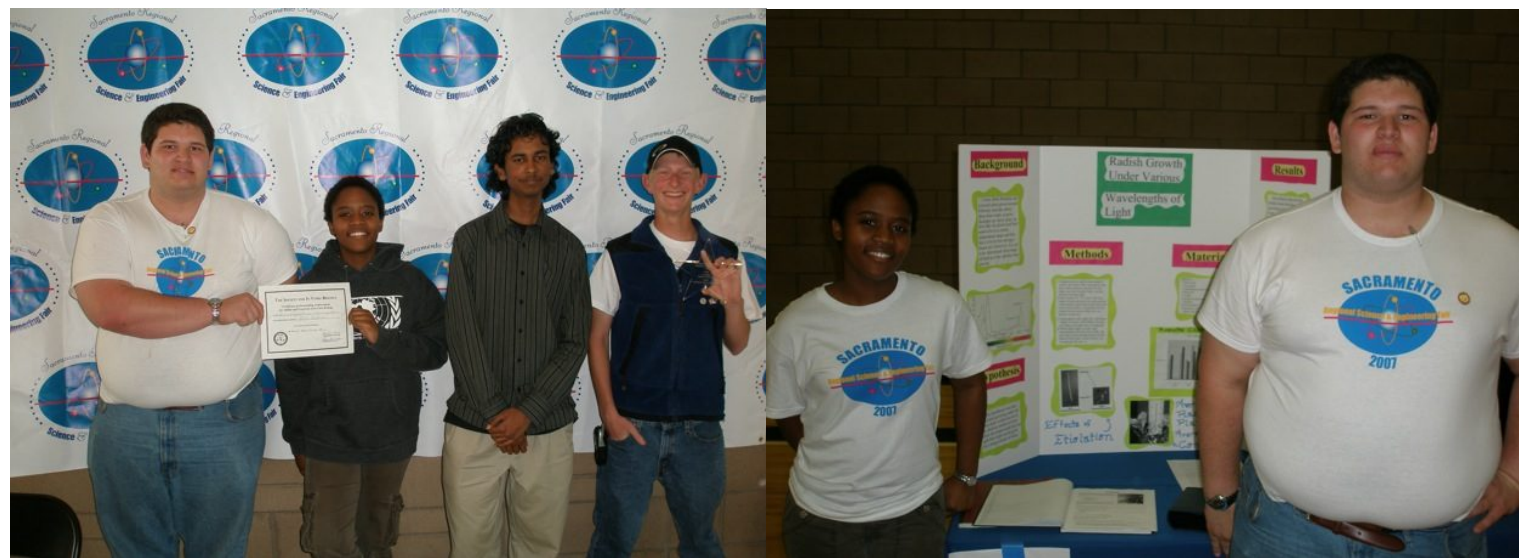

Fig. 3. Two teams of Center High School winners from the Sacramento Regional Science and Engineering Fair. 


\subsection{Program Design 3: Multi-Year Course}

The year-round elective course was first attempted in the 2005-2006 school year at East Oakland Community High School (EOCHS, a community charter school). EOCHS is a school serving a primarily underrepresented population in the inner city. Local CBST researcher, Susan Spiller, from Mills College, along with several of her post-baccalaureate students have acted, and continue to act as program mentors working in collaboration with the current science teacher at the school. The Academy focuses on biophotonics and plants, reflecting the expertise of Susan Spiller and matching with the school focus on community and environment. Due to heavy teacher turnover and the 90 mile distance to the CBST main headquarters, the program is having some difficulties becoming fully established. Pictured at right is mentor Stephanie Lane working in the laboratory with one of the students in the course.

In an effort to establish a more local, multi-year course, a partnership with the UC Davis Cancer Center and the local St. Hope Academy at inner city Sacramento High School was

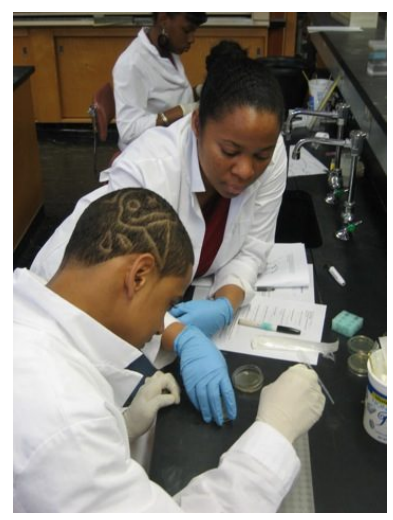
developed. The resulting program, the CURE High School Research Academy, is funded through a combination of CBST funds and the "P30 Supplement" to the UC Davis Cancer Center NIH Grant. Per the "P30 Supplement" grant, the aims of the CURE program are to: (1) offer a two-year cancer science curriculum consisting of didactic and experiential learning in basic, clinical and population sciences for three successive cohorts of 20 high school students from Sacramento High School; (2) attract, recruit and enroll these students during the second semester of their ninth or tenth grade; (3) document and measure progress; (4) help prepare these students for entry into four-year institutions with a greater aptitude for and probability of selecting cancer-relevant majors; (5) track and longitudinally report the achievements of CURE students and alumni; and (6) document and disseminate lessons learned.

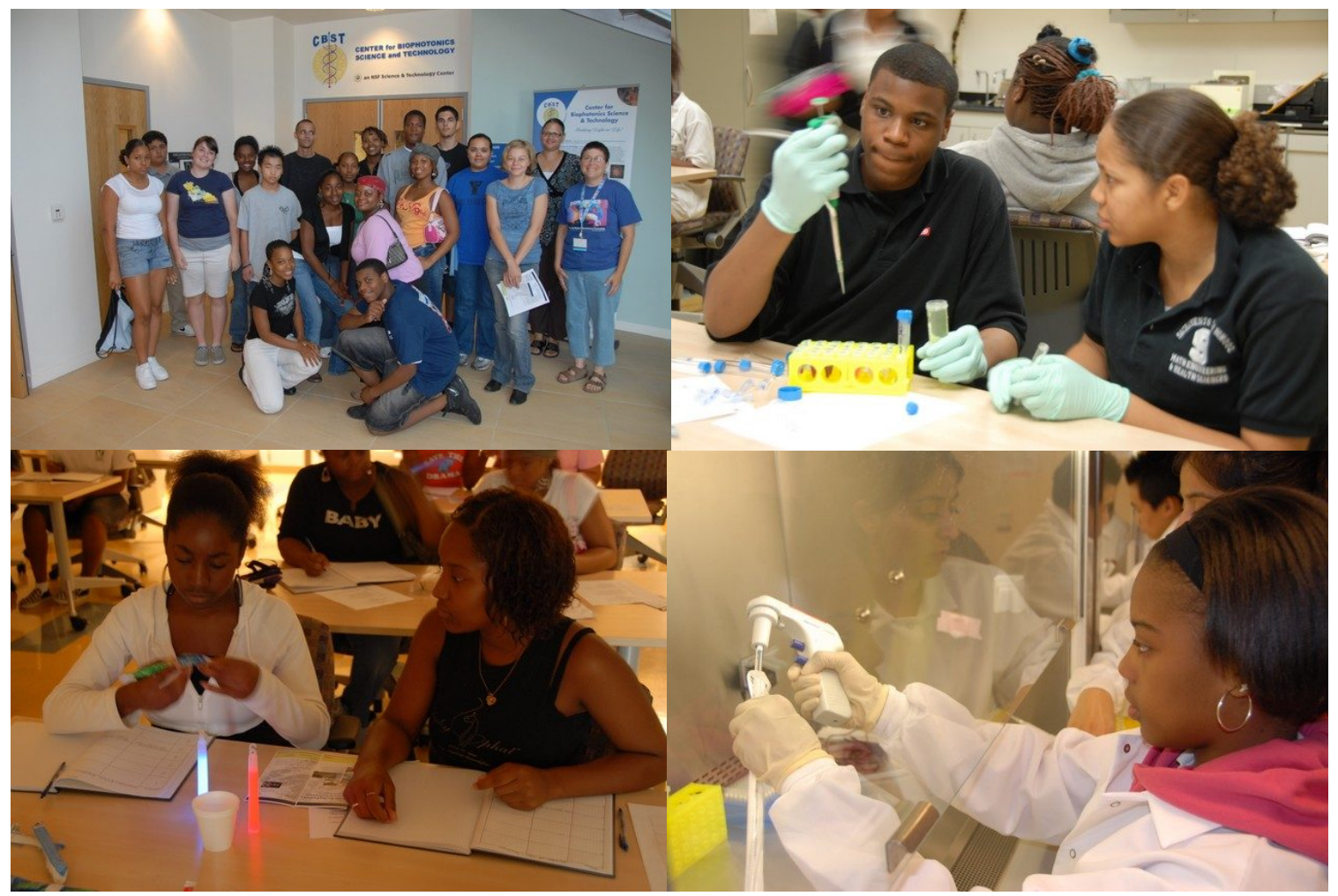

Figure 4: CURE students engaged in various basic biophotonics and biology laboratory experiments.

The CURE Academy is implemented as a regular science course offering at the Science, Math, Engineering and Health Academy at Sacramento High School, a St. Hope Academy Public Charter school. To ensure that the courses have 
relevance in college applications, we have applied for approval of the CURE course to be an A-G college preparatory laboratory science course. A-G approval would show University of California recognition of the biophotonics course as fulfilling the laboratory requirement for students applying for University of California admittance. During spring, 2006, 20 students were selected from a pool of 30 applicants through competitive application reviews and interviews. All 20 students selected for the first student cohort participated in the first semester of the program; however, two left the program during the second semester (one because she moved, and the other because he was unable to fulfill the requirements and expectations of the program). Thus, 18 students completed the first year of CURE (15 from underrepresented groups as defined by the National Science Foundation). The average cumulative GPA of the cohort is 3.43 .

The lead teacher for the CURE program is Angela Jones, a UCD graduate who worked for four years as a laboratory assistant at the Cancer Center. The curriculum emphasis during the first year was basic science, see Table 1. The basic science faculty team included Drs. Marco Molinaro, Ana Corbacho, Pam Castori, and Frank Chuang. This first cohort spent 270 hours of classroom instruction (a class period is 90 minutes long and there are 180 days of instruction); they spent at least 40 hours participating in after school laboratory and field trip experiences, another 6 hours in a summer orientation, and will spend 80 hours in their first summer research experience (June $4-21$ ). Total learning time for Cohort I of Year I of the CURE program is estimated to be 396 hours, a substantial commitment by both students and faculty. Of this time, approximately $40 \%$ is didactic teaching and $60 \%$ is hands-on laboratory activity.

\begin{tabular}{|c|c|c|}
\hline & Year 1 Modules & Topics \\
\hline \multirow{3}{*}{ 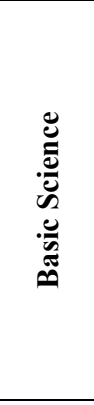 } & $\begin{array}{l}\text { Module 1: Introduction to Cancer } \\
\text { Biology, Biophotonics, Scientific } \\
\text { Investigation, Information Technologies }\end{array}$ & $\begin{array}{l}\text { What is cancer? What technologies are useful in studying } \\
\text { cancer? How does cancer science happen? What kinds of } \\
\text { work do cancer scientists do? What tools, techniques, and skills } \\
\text { will we use to study cancer? }\end{array}$ \\
\hline & $\begin{array}{l}\text { Module II: Experiences in Light Basics } \\
\text { for Biophtonics }\end{array}$ & $\begin{array}{l}\text { electromagnetic spectrum, nature of light, light and color, } \\
\text { absorption, transmission, reflection, optics, light sources, } \\
\text { light/tissue interaction, spectroscopy }\end{array}$ \\
\hline & $\begin{array}{l}\text { Module III: Experiences in Biology } \\
\text { Basics for Oncology }\end{array}$ & $\begin{array}{l}\text { cell biology, gene expression, cell cycle, cellular } \\
\text { differentiation, cell signaling, life and death of a cell, cancer } \\
\text { biomedicine, causes of cancer, diagnosis, treatment, goals in } \\
\text { cancer medicine }\end{array}$ \\
\hline \multirow[t]{2}{*}{ 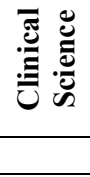 } & $\begin{array}{l}\text { Module IV: Cancer detection, diagnosis } \\
\text { and treatment using Biophotonics: }\end{array}$ & $\begin{array}{l}\text { optical methods, tumor imaging, photodynamic therapies, } \\
\text { image-guided surgery, cell and bacteria diagnostics, non- } \\
\text { invasive optical diagnostics, confocal laser scanning techniques }\end{array}$ \\
\hline & Year 2 Modules & Topics \\
\hline 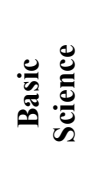 & $\begin{array}{l}\text { Module I: Molecular and Cell Biology of } \\
\text { Cancer (Basic cancer science) }\end{array}$ & $\begin{array}{l}\text { Characteristics of cancer, understanding cancer as a disease, } \\
\text { classification, diagnostic procedures, carcinogenesis, cellular } \\
\text { differentiation and progressions of malignant behavior, } \\
\text { oncogenes, cell cycle regulators, gene } \\
\text { transcription/transduction, cancer therapies }\end{array}$ \\
\hline 预 & Module II: Clinical Science & $\begin{array}{l}\text { Cancer diagnosis and treatment: cancer of different tissues } \\
\text { (e.g. lung, breast, prostate, skin, blood, etc.), cancer typing and } \\
\text { staging, clinical tests, radiological imaging, surgical biopsy, } \\
\text { treatments (surgery, radiation and chemotherapy); life as an } \\
\text { MD, clinical duties, careers in clinical cancer science }\end{array}$ \\
\hline \multirow[t]{2}{*}{ 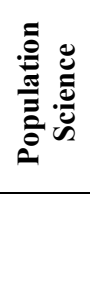 } & Module III: Population Science & $\begin{array}{l}\text { Cancer prevention and control in human populations: role and } \\
\text { controversies associated with nutrition and obesity; health } \\
\text { communication and consumer health education, environmental } \\
\text { influences, cancer screening, role of culture and behavior, and } \\
\text { research topics. }\end{array}$ \\
\hline & $\begin{array}{l}\text { Module IV: Lab skills for Cancer } \\
\text { Science (INTEGRATED INTO OTHER } \\
\text { MODULES) }\end{array}$ & $\begin{array}{l}\text { gel electrophoresis, PCR, microscopy, spectroscopy, advanced } \\
\text { imaging techniques, bioinformatics }\end{array}$ \\
\hline
\end{tabular}

Table. 1. High School Biophotonics Research Academy Biophotonics and Cancer Science Curriculum. 


\section{Program Assessment and Evaluation}

The High School Research Academy in Biophotonics, no matter which program design is utilized, involves substantial effort from students, educators, and researchers, as well as substantial financial resources that increase based on design complexity. In an effort to improve the program and provide concrete data as to its effectiveness, a substantial evaluation effort has been undertaken at the formative and summative levels. The various instruments created for the purpose of assessing student gains in a pre/post fashion are listed in Table 2 below.

Partial evaluation outcomes from the last 2 years indicate (1) significant changes in students' understanding of the processes, skills and values of science; (2) significant change in students' understanding of the discipline of biophotonics; (3) changes in students' course choices for math/science (increase in AP course choices); and (4) change in students' interests in pursuing STEM-related majors and careers. More extensive data collection and analysis efforts are currently underway.

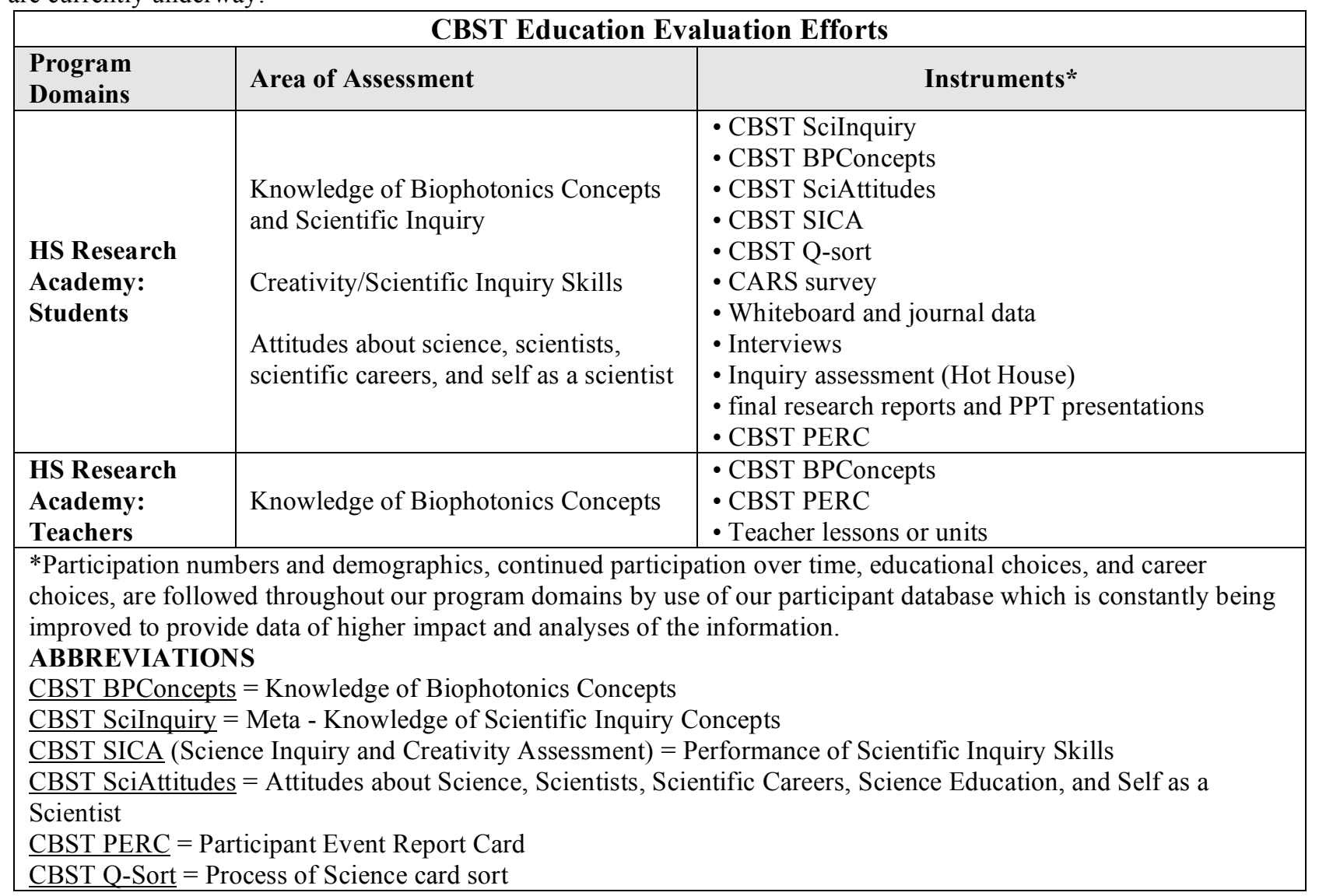

Table. 2. High School Biophotonics Research Academy Evaluation Efforts and Instruments.

\section{Program Challenges and Surprises}

In the last three years of working with the High School Research Academy in Biophotonics design, various challenges and surprises have arisen. A few of the main challenges and surprises are presented here in bulleted form.

- Teacher experience and turnover -Many schools in the United States are undergoing frequent teacher turnover as more capable teachers seek better opportunities in wealthier districts. In poorer, inner city districts, younger, less experienced teachers appear to be the norm. Starting teachers usually bring with them high motivation but lack experience in maintaining classroom discipline, a substantial drawback in a team-based, less structured, nonrote based experiences such as that presented by the Biophotonics Academy.

- Large support structure needed - To successfully engage high school students in doing authentic research related 
to biophotonics requires a substantial and diverse team. The teacher involved has to be open to being less of a "sage on the stage" and more of a "guide on the side" and be willing to take risks in an area of expertise usually foreign to them. Researchers with an educational background or interest need to be present to provide a real connection to the current research, acting both as an expert in the topic and an open and willing communicator that is able to simplify very complex ideas. More often than not the last role mentioned is fulfilled by 2 or more persons, usually a scientist turned educator acts as a translator for one or more researchers. Undergraduate mentors act as a very helpful, and less formal, bridge between the world of high school and that of university, especially when the student population is from a disadvantaged socioeconomic background and has little to no experience with the collegiate world. Lastly, a willing principal and school administration needs to understand the value of the program and support out of class activities such as field-trips and visits to laboratories for more extensive research experiences.

- The course or courses need to matter academically - Biophotonics Academies can be the equivalent of two full courses plus require substantial time outside of the classroom and in the summer. In all cases when a student choses biophotonics they are having to remove another class from their schedule. While we all tend to believe that experiential learning and authentic research are invaluable experiences, the students still need to graduate on time and be on track for college/university admission. Making the experience count towards college entrance can be the critical factor for making the experience sufficiently valuable academically. This also means that the course needs to be rigorous and contain enough assessments to accurately reflect the students' performances.

- Long term sustainability - While our programs are not yet self sustained it is clear that substantial funding and training over several years are needed to have a chance at sustainability. Simpler program designs such as the in-course modules are likely much easier to sustain but a range of levels will hopefully lead to the greatest student exposure over time.

\section{Future Plans and Conclusions}

We are intending to continue the high school program at various local high schools for as long as possible. Current focus is on long-term sustainability. No new full year commitments with new high schools are added unless they come with the funds necessary to fund CBST educational staff (part-time), teacher development time, and base equipment for multiple years. Towards that end, in Fall 2006, a grant proposal was submitted to the Howard Hughes Medical Association for a HSRAB program with an emphasis in Biomedical Sciences to be created in collaboration with the West Sacramento School District/River City High School. This proposal would fund the training of middle and high school teachers to implement program designs 1 and 3 (in-course modules and full courses) over the span of 5 years with equipment funds to create stations to support up to two simultaneous classes. The equipment envisioned, an upgrade to the CBST teacher kit mentioned in Section 2.1, would serve the school in biophotonics related experiments that could arise in biophotonics, biology, chemistry, environmental science, and physics related classes. Our long term hope is that by incorporating biophotonics concepts and techniques throughout the science curriculum, many more students can enter college and university better prepared to comprehend and conduct research in biophotonics and science in general.

\section{ACKNOWLEDGEMENTS}

The Center for Biophotonics Science and Technology (CBST) is funded by the National Science Foundation and is managed by the University of California, Davis under Cooperative Agreement No. PHY 0120999.

Additional funding for the St, Hope Academy at Sacramento High School provided by the P30 CURE Supplement to the University of California Davis National Cancer Institute grant.

We also wish to acknowledge Center High School in Antelope, CA, East Oakland Community High School in Oakland, CA, and the St. Hope Academy at Sacramento High School in Sacramento, CA, for their continued support of our program.

\section{REFERENCES}

[1] Paras N. Prasad, Introduction to Biophotonics, Wiley-Interscience, Hoboken, NJ, 2003.

[2] Science and Technology Centers: Integrative Partnerships, NSF Document 03-550, National Science Foundation, Arlington, VA, 2003. 